\title{
Correction: Premature activation of Cdk1 leads to mitotic events in $S$ phase and embryonic lethality
}

\author{
Radoslaw Szmyd · Joanna Niska-Blakie - M. Kasim Diril • Patrícia Renck Nunes • Konstantinos Tzelepis • \\ Aurélie Lacroix · Noémi van Hul • Lih-Wen Deng • Joao Matos • Oliver Dreesen • Xavier Bisteau • Philipp Kaldis
}

Published online: 21 November 2019

(c) The Author(s) 2019. This article is published with open access

\section{Correction to: Oncogene}

https://doi.org/10.1038/s41388-018-0464-0

The original version of this article contained an error in the author affiliations.

Affiliation number 7 incorrectly read 'Izmir Biomedicine and Genome Institute, Dokuz Eylul University, 35340 Izmir, Turkey". It should be "Izmir Biomedicine and Genome Center, Dokuz Eylul University Health Campus, 35340, Izmir".
Open Access This article is licensed under a Creative Commons Attribution 4.0 International License, which permits use, sharing, adaptation, distribution and reproduction in any medium or format, as long as you give appropriate credit to the original author(s) and the source, provide a link to the Creative Commons license, and indicate if changes were made. The images or other third party material in this article are included in the article's Creative Commons license, unless indicated otherwise in a credit line to the material. If material is not included in the article's Creative Commons license and your intended use is not permitted by statutory regulation or exceeds the permitted use, you will need to obtain permission directly from the copyright holder. To view a copy of this license, visit http://creativecommons. org/licenses/by/4.0/. 